DOI: 10.17707/AgricultForest.65.4.17

\author{
Olivera NIKOLIC, Milanko PAVLOVIC, \\ Dragan DEDIC, Vladimir SABADOS ${ }^{1}$
}

\title{
THE INFLUENCE OF SOW DENSITY ON PRODUCTIVITY AND MOISTURE IN BUCKWHEAT GRAIN (Fagopyrum esculentum Moench.) IN CONDITION OF STUBBLE SOWING AND IRRIGATION
}

\begin{abstract}
SUMMARY
The important role of buckwheat in moder human diet and contemporary, sustainable agriculture derives from its chemical composition of grain and modest growing requirements. Consequently, there is an increasing trend of areas under buckwheat with a rate of $22.46 \%$ per year. Buckwheat arouses great interest as essential ingredient for functional foods because of its health benefits. Its grain is one of the best sources of high quality protein in the plant kingdom. Buckwheat is very sensitive to the lack of moisture, especially during the first development phases, in period of rooting, during flowering and yielding period. So, the aim of investigation was to estimate the optimal seed rate of buckwheat to achieve the productive, economic and other objectives, especially important for ecological agriculture, in conditions of stubble sowing and irrigation. The investigation included 12 genotypes and three sowing density (80,120 and 160 grains $\mathrm{m}^{-2}$ ).

The highest average grain yield is obtained in density of 160 grains per $\mathrm{m}^{-}$ ${ }^{2}$, then in density of 120 grains per $\mathrm{m}^{-2}$, but the lowest in 80 grains per $\mathrm{m}^{-2}$ density. Difference in grain yield between 160 grains per $\mathrm{m}^{-2}$ and 120 grains per $\mathrm{m}^{-2}$ density variants is a slight, only $80 \mathrm{~kg}$ or $3.49 \%$ that means both sowing density variant could be applied successfully in buckwheat planting technology, but sowing density of 120 grains per $\mathrm{m}^{-2}$ has priority because of production economics.
\end{abstract}

Key words: buckwheat, density, grain yield, irrigation.

\section{INTRODUCTION}

Buckwheat is plant species known for centuries and has cultivated, according to recent evidence, more than 7000 years (Ohnishi et al., 1998). It originates from the mountainous parts of central and northeast Asia, Junan and Sečuan provinces. Due to nomadic tribes, buckwheat has been spread to the

\footnotetext{
${ }^{1}$ Olivera Nikolic, *(corresponding author: olivera.nikolic@educonss.edu.rs), Milanko Pavlovic, EDUCONS University, Faculty of Ecological Agriculture, Vojvode Putnika 87, 21208 Sremska Kamenica, SERBIA; Dragan Dedic, The Ministry of Agriculture, Forestry and Water Management, Nemanjina 24, 11000 Belgrade, SERBIA; Vladimir Sabados, APS Sombor, Staparski put 25, 25000 Sombor, SERBIA.

Notes: The authors declare that they have no conflicts of interest. Authorship Form signed online.
} 
Balkan Peninsula in the, most likely, $13^{\text {th }}$ century. It is interesting that buckwheat is one of the few plant species transferred from Europe to America, during 16th century. For a long time, it has been neglected plant species, excluded from production, human and animal nutrition. Buckwheat exhibits, very often, characteristics of wild, uncultivated plant species, sensitive to mineral fertilizers (Kreft et al., 2008). Such characteristics like modest demands, economy and good competitive ability recommends it for ecological farming system (Gadzo et al., 2009; Dedic, 2012).

Nowadays, buckwheat is planted to an average of 2.113 million hectares worldwide. There is an increasing trend of areas under buckwheat with a rate of $22.46 \%$ per year. The highest production of buckwheat of $93.67 \%$ in the world was in Europe and on Asian continent (1.133 ha, 846.799 ha), that is $53.61 \%$ and $40.06 \%$, respectively. The most significant producers of buckwheat in the world are: China (34.25 \%), Russia (32.43 \%) and Ukraine (11.46 \%) (Popovic et al., 2014).

Buckwheat arouses great interest as essential ingredient for functional foods because of its health benefits (Li et al., 2001; Zhang et al., 2012). Its grain is one of the best sources of high quality protein in the plant kingdom. It contains about $52.11 \%$ starch, $11-12.55 \%$ of the total protein, $8.7 \%$ of the pulp, $2.23 \%$ oil, $11 \%$ water and $1.75 \%$ of $\mathrm{N}$ protein (Popovic et al., 2013). The most important ingredients of this plant are flavonoids (Arsic et al., 2008). Grain contains a large amount of indispensable amino acids (EAA), primarily lysine and methionine and dietary protein, vitamins $\mathrm{B}_{1}$ and $\mathrm{B}_{2}$, minerals like $\mathrm{Fe}, \mathrm{Zn}$ and Se (Bavec and Bavec, 2006). The presence of antioxidants like rutin, tannin and fagopyrin has special importance (Kreft et al., 2006). Complete grain is used as a nutritive supplement for different stews, while flour is used for preparation of porridge (polenta) or mixed with wheat or rye for preparation of bread with higher digestion value. Because of the beneficial chemical composition, and the absence of adhesive proteins, buckwheat is suitable for diabetics and children diets. Like a honey plant, buckwheat is very useful for bees throughout the entire summer and fall period in absence of other flowered plants. Buckwheat honey contains increased amounts of bioflavonoids that have antibacterial effects (Janovska et al., 2008).

At the same time, buckwheat crops protect the soil from erosion, attract beneficial insects and raise the level of organic matter in the soil (Wallace, 2001). Barac et al. (2012) emphasized the importance of the threshing device on a harvester and quality of harvesting for the quality of the threshed grain. The properly done this phase is very important to keep and care quality of seed products.

The aim of investigation was to estimate the optimal seed rate of buckwheat to achieve the productive, economic and other objectives, especially important for ecological agriculture, in conditions of stubble sowing and irrigation. 


\section{MATERIAL AND METHODS}

\section{Climate and soil conditions during experiment conducting}

Buckwheat is very sensitive to the lack of moisture, especially during the first development phases, in period of rooting, during flowering and yielding period. During the later phases, excess of moisture causes a lot of negative effects. It has very high transpiration coefficient, up to 700 (Janovska et al., 2008). Influences of temperatures are rather strong, too.

During 2010, 360.4mm precipitation were in May and Jyly, while $125.6 \mathrm{~mm}$ precipitation only or almost three times less were in the same period in 2011. It means that 2010. was more favorable in term of soil moisture, necessary for germination. During July and August, almost the same precipitation sums $(120 \mathrm{~mm}$, averagely) were in the both of investigation years in generative phase (impregnation and grain filling phases) (Table 1).

Table 1. Distribution and total precipitation $(\mathrm{mm})$ in growing season at Sombor locality

\begin{tabular}{|c|c|c|c|c|c|}
\hline \multirow{2}{*}{ Year } & \multicolumn{4}{|c|}{ Month } & $\begin{array}{c}\text { Total precipitation in growing } \\
\text { season (mm) }\end{array}$ \\
\cline { 2 - 5 } & V & VI & VII & VIII & \\
\hline 2010 & 166 & 194.4 & 77 & 44.2 & 481.6 \\
\hline 2011 & 67.8 & 57.8 & 66.6 & 50.4 & 242.6 \\
\hline
\end{tabular}

This precipitation sum could be limiting factor to obtain more yield per unit area because it is critical period for buckwheat. Several irrigation doses, however, made goog conditions for yielding.

Air temperatures in vegetative phase of development (intensive growth of trees and branching) were very favorable during the both of investigation years (Table 2).

Table 2. Air temperatures $\left({ }^{0} \mathrm{C}\right)$ during vegetative seasons at Sombor locality

\begin{tabular}{|c|c|c|c|c|c|c|c|c|c|c|c|c|}
\hline \multirow{3}{*}{ Year } & \multicolumn{10}{|c|}{ Month } \\
\cline { 2 - 15 } & \multicolumn{3}{|c|}{ V } & \multicolumn{3}{|c|}{ VI } & \multicolumn{3}{c|}{ VII } & \multicolumn{3}{c|}{ VIII } \\
\cline { 2 - 14 } & $\min$ & $\mathrm{X}$ & $\max$ & $\min$ & $\mathrm{X}$ & $\mathrm{Max}$ & $\min$ & $\mathrm{X}$ & Max & $\min$ & $\mathrm{X}$ & $\max$ \\
\hline 2010 & 12.1 & 16.9 & 21.8 & 15.6 & 20.3 & 24.9 & 17.6 & 23.1 & 28.6 & 15.7 & 21.8 & 27.9 \\
\hline 2011 & 10.2 & 16.6 & 23.0 & 15.1 & 21.0 & 26.9 & 15.8 & 21.9 & 28.0 & 15.6 & 22.7 & 29.7 \\
\hline
\end{tabular}

Buckwheat does not tolerate high temperatures. Growth is already slowing down at $28^{\circ} \mathrm{C}$, as the percentage of impregnation and grain formation (Glamoclija, 2011).The optimal temperature for grow and development is $20^{\circ} \mathrm{C}$ while temperatures above $30^{\circ} \mathrm{C}$, during flowering phase, followed by low air moisture, cause drying and falling flowers and bad pollination (Pauseva, 1976). 
There were not extreme temperatures which could limit normaly fertilization and yielding during this experiment.

The trial was set up on carbonate meadow black soil, with wheat as preceding crop, on field of APS "Sombor" in Sombor, Serbia as double cropping system, during 2010. and 2011., under irrigation. The investigation included 12 genotypes: P2, P4, P5, P6, P9, P10 and P11, as domestic and foreign populations, Darja, Bamby, Oberon and Bylly, as foreign cultivars and Novosadska, as domestic cultivar. The experiment was designed as block system, in three replications, with area of elementary plot $20 \mathrm{~m}^{2}$. Distance between rows was 25 $\mathrm{cm}$. Sowing was in acordiance with planned sowing density (80, 120 and 160 grains $\mathrm{m}^{-2}$ ). The sowing was done on $15^{\text {th }}$ July in 2010, but on $9^{\text {th }}$ July in 2011 . The plants were irrigated three times: in phase of intensive growth of trees and branching, 15 days after and in phase of intensive flowering and yielding, with $25 \mathrm{l}$ water per $\mathrm{m}^{-2}$, each time. The harvest was done in moment when $2 / 3$ of yield were riped respectively when grains of the latest genotype were dark brown. The harvest was one - phased, done on $20^{\text {th }}$ August, in 2010. and on $12^{\text {th }}$ August, in 2011. The grain yield was measured per each plot and appropriate sowing density. On the base of that, average yield was calculated and expressed as grain yield with $13 \%$ of moisture.

\section{Statisticall analysis}

Data were analyzed statistically using two factorial model of analysis of variance according to Hadzivukovic (1973). The differences of means were tested using an LSD test at $\mathrm{p}=0.05$ and $\mathrm{p}=0.01$ probability levels.

\section{Grain yield}

\section{RESULTS AND DISCUSSION}

Buckwheat is grown primarily due to grain. Grain yield is quantitative trait influenced by genotype, external factors and applied growing technology. After harvest, it is necessary to free the grain from the harvest residues and inert matter, as soon as it is possible.

Investigated genotypes obtained high and stabile grain yield in sowing density of 160 grains $\mathrm{m}^{-2}$ in 2010. $\mathrm{P}_{2}$ and $\mathrm{P}_{11}$ gained yield above $3 \mathrm{t} \mathrm{ha}^{-1}$. The most of genotypes $\left(\mathrm{P}_{2}\right.$, Darja, $\mathrm{P}_{4}$, NS plus, $\mathrm{P}_{6}, \mathrm{P}_{11}$, Bylly) gained yield between 2.5 and $3 \mathrm{t} \mathrm{ha}^{-1}$ in sowing density of 120 grains $\mathrm{m}^{-2}$, while significant grain yield decline was noticed in all genotypes, in sowing density of 80 grains $\mathrm{m}^{-2}$ (Graph.1).

According to grain yield and its dependence on sowing density, during 2011, buckwheat genotypes were divided in two groups: with more variable and higher grain yield above $2 \mathrm{t} \mathrm{ha}^{-1}\left(\mathrm{P}_{2}\right.$, Darja, $\mathrm{P}_{4}$, NS plus, $\left.\mathrm{P}_{6}\right)$ and with less variable and medium grain yield - between 1 and $2 \mathrm{t} \mathrm{ha}^{-1}$ (Oberon, Bamby, Novosadska, $\mathrm{P}_{9}, \mathrm{P}_{10}, \mathrm{P}_{11}$, Bylly) (Graph.2). 


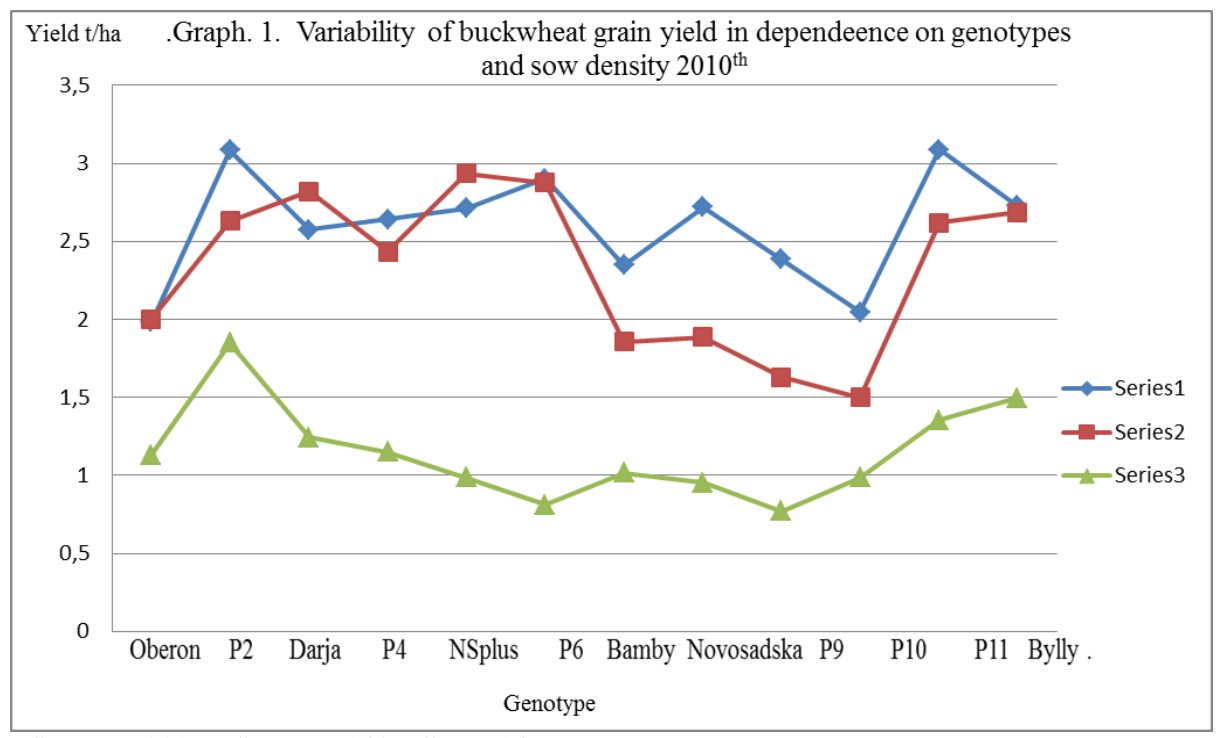

$\mathrm{LSD}_{0.05}=111 ; \mathrm{LSD}_{0.01}=148 ; \mathrm{CV}=5.86$

Legend: series 1 - 160 grains $\mathrm{m}^{-2}$; series $2-120$ grains $\mathrm{m}^{-2}$; series $3-80$ grains $\mathrm{m}^{-2}$

Graph 1. Variability of buckwheat grain yield depending on genotype and sowing density in 2010.

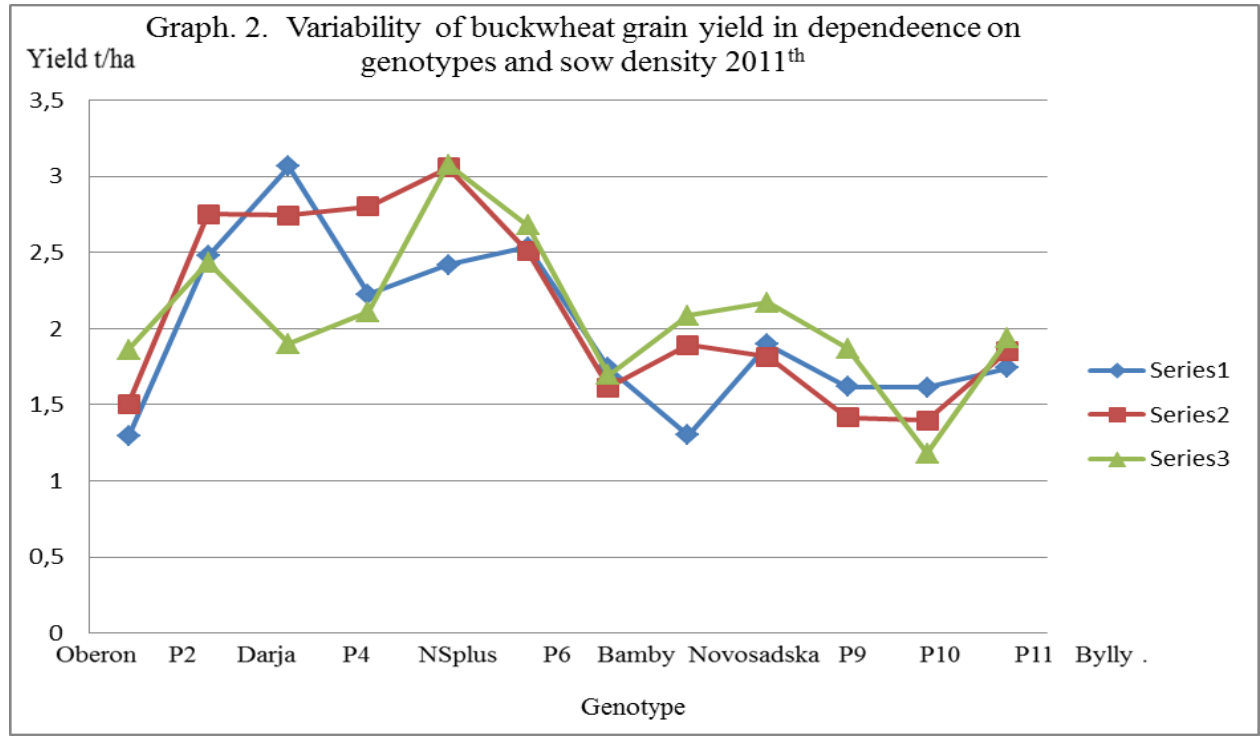

$\mathrm{LSD}_{0.05}=62 ; \mathrm{LSD}_{0.01}=82 ; \mathrm{CV}=3.18$

Legend: series 1-160 grains $\mathrm{m}^{-2}$; series 2-120 grains $\mathrm{m}^{-2}$; series 3-80 grains $\mathrm{m}^{-2}$

Graph 2. Variability of buckwheat grain yield depending on genotype and sowing density in 2011. 
These results are in accordinace with previous results reported by Popovic et al. (2014) and Gadzo et al. (2007). However, cited authors planted buckwheat as main crop, without irrigation. In such conditions, influences of external factors are more expressed. Further analysis leads to observation that adequate yields can be achieved by reduction of seed quantity, with applying new growing technologies and more productive genotypes and populations. These two years results show that sowing density of 120 grains $\mathrm{m}^{-2}$ is economical and efficient in the given conditions.

Considering average grain yield, during each of investigated years, at all of three sow rates, it can be observed that almost a half of genotypes (Oberon, P2, Bamby, Novosadska, P10) obtained stable average yields and showed less sensitivity to environmental influence during investigation years. Population P2 stands out, with yields over $2.5 \mathrm{t}$ ha-1. The strongest environmental influence was registered on genotype NS plus and population P11 (Tab.3).

Table 3. Stability of grain yield of investigated buckwheat genotypes in 2010. and 2011.

\begin{tabular}{|l|l|l|l|l|l|l|l|l|l|l|l|l|}
\hline \multirow{2}{*}{\begin{tabular}{c} 
むँ \\
\cline { 2 - 14 }
\end{tabular}} & Oberon & P2 & Darja & P4 & $\begin{array}{l}\text { NS } \\
\text { plus }\end{array}$ & P6 & Bamby & $\begin{array}{l}\text { Novo } \\
\text { sadska }\end{array}$ & P9 & P10 & P11 & Bylly \\
\hline 2010 & 1.56 & 2.56 & 2.57 & 2.38 & 2.85 & 2.57 & 1.68 & 1.76 & 1.96 & 1.64 & 1.40 & 1.84 \\
\hline 2011 & 1.71 & 2.52 & 2.22 & 2.07 & 2.21 & 2.20 & 1.74 & 1.85 & 1.60 & 1.51 & 2.35 & 2.30 \\
\hline
\end{tabular}

Popovic et al. (2014) noticed that favorable climatic conditions and adequate planting technology have important influence on yield while this investigation pointed out importance of genetic structure of genotype and population and interaction genotype $\mathrm{x}$ environment.

This investigation points to the possibility of buckwheat croping in lowland areas, irrigation and double cropping system obtaining more yields than average ones in world.

Table 4. Average buckwheat grain yield in dependence on sowing density

\begin{tabular}{|c|c|c|c|c|c|c|c|c|}
\hline \multirow{2}{*}{\multicolumn{2}{|c|}{ Year }} & \multicolumn{3}{|c|}{ 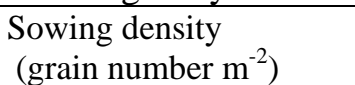 } & \multirow[t]{2}{*}{ Yield (kg) } & \multicolumn{2}{|l|}{ LSD } & \multirow[t]{2}{*}{ CV } \\
\hline & & 160 & 120 & 80 & & 0.05 & 0.01 & \\
\hline 2010 & \multirow{3}{*}{$\begin{array}{l}\text { Grain } \\
\text { yield } \\
\text { (kg) }\end{array}$} & 2.601 & 2.323 & 1.145 & 2.023 & 111 & 148 & 5.86 \\
\hline 2011 & & 1.994 & 2.114 & 2.083 & 2.064 & 62 & 82 & 3.18 \\
\hline $2010 / 2011$ & & 2.298 & 2.218 & 1.614 & 2.043 & 63 & 83 & 4.69 \\
\hline
\end{tabular}

Different sowing density influnces grain yield of some genotypes and average grain yield in different sowing density variants while average grain yield in investigation years do not vary significantly (Tab. 4). The highest average grain yield is obtained in density of 160 grains per $\mathrm{m}^{-2}$, then in density of 120 grains per $\mathrm{m}^{-2}$, but the lowest in 80 grains per $\mathrm{m}^{-2}$ density. The increases of grain yield in 160 grains per $\mathrm{m}^{-2}$ and 120 grains per $\mathrm{m}^{-2}$ density variants in relation to 
variant of 80 grain per $\mathrm{m}^{-2}$ are $684 \mathrm{~kg}(29.77 \%)$ and $604 \mathrm{~kg}$ (27.24\%), respectively. Difference in grain yield between 160 grains per $\mathrm{m}^{-2}$ and 120 grains per $\mathrm{m}^{-2}$ density variants is a slight, only $80 \mathrm{~kg}$ or $3.49 \%$. It means that both sowing density variant could be applied successfully in buckwheat planting technology, but sowing density of 120 grains per $\mathrm{m}^{-2}$ has priority because of production economics. Less sowing density, $80 \mathrm{~kg}$ per ha ${ }^{-1}$, is recommended for earlier sowing times, but later sowing, like double cropping system, requires a higher amount of seeds, above $100 \mathrm{~kg}$ per ha- ${ }^{-1}$ (Rotim et al., 2012). Lower sowing density decreases production cost, but sowing density, however, have to provide such crop structure that will improve the effectiveness of weed control (Bavec et. al., 2006). Omid Beygi et al. (2002) studied effects of different nitrogen amounts and sowing density on plants growing, grain yield and rutin content and concluded that density of 100 plants per $\mathrm{m}^{-2}$ and total amount of 100 $\mathrm{kgN}$ per ha ${ }^{-1}$ give the best results. Gavric et al. (2018) registered significant influence of sowing density and meteorological conditions on grain yield of buckwheat, too, but not to chemical compose of grain. Increasing sowing rate had positive effect on grain yield, but it had no effect on chemical compose of kernel. The same authors noticed that unfavorable weather conditions (drought and high temperature) resulted in low average yield, but in high grain quality i. e. high content of crude protein, starch and total phenol in grain.

\section{Grain moisture}

Harvesting buckwheat is the most important agrotechnical procedure in system of plamting technology required flawless planning and proper doing. It can be as one phase, like in this trial and two phases process.

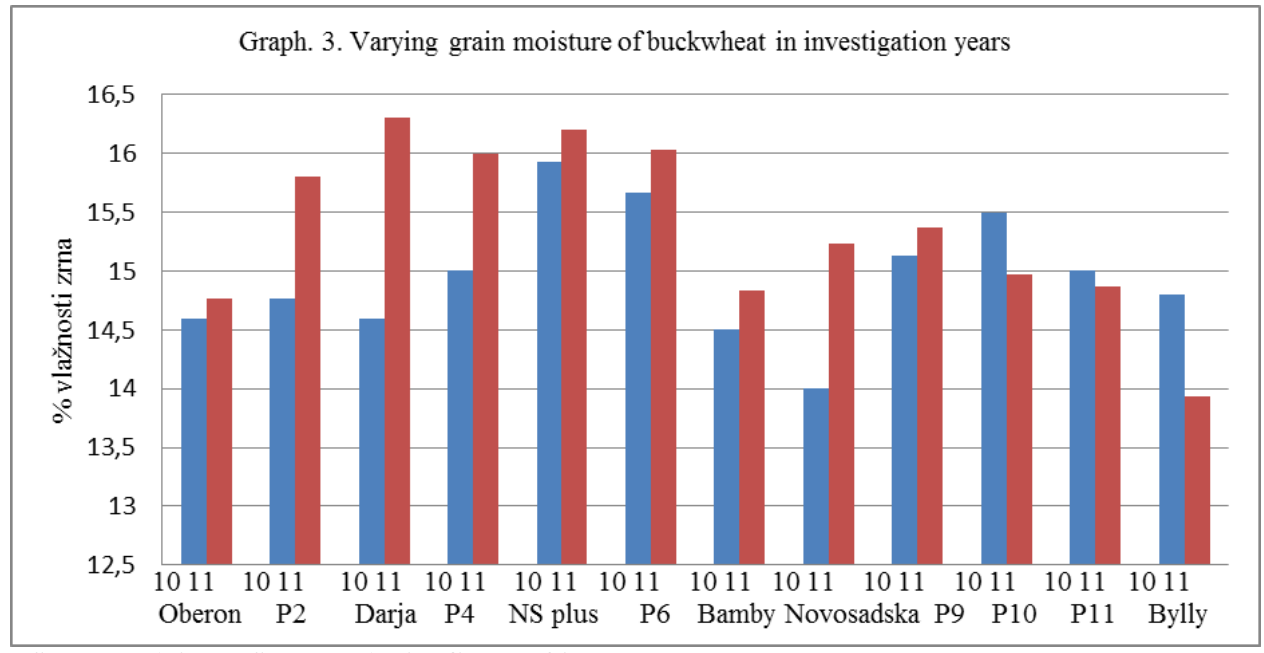

$\mathrm{LSD}_{0.05}=1.29 ; \mathrm{LSD}_{0.01}=1.72 ; \mathrm{CV}=7.32$

Legend: series 10-2010; series 11-2011.

Graph 3. Varying grain moisture of buckwheat in investigation years 
One phase harvest is performed at the moment of high percent of moisture and inert matters in grains, catching up parts of biomass (leaves, branches and stems). Therefore, it is necessary to carry out the grain drying and separation, immediately after harvest. Two phases haarvest means mowing and hay drying and, after that, treshing on different treshing machines. The importance of determinaation of grain moisture is reflected in decrease losses, drying and entire production costs as well as preserving the grain quality of buckwheat for a longer period.

Grain moisture varried from $14.0 \%$ to $15.93 \%$, and from 13.93 to $16.3 \%$. in 2010. and 2011., respectively. Differences in grain moisture between investigation years are not significant for most of genotypes, except for Darja (1.7\%) and NS buckwheat (1.23\%) (Graph. 3.)

Results presented in Table 5. show that there are not differences in grain moisture in various sowing density variants in both of years.

Table 5. Average values of grain moisture of buckwheat depending on sowing density

\begin{tabular}{|c|c|c|c|c|c|c|c|c|}
\hline Year & \multirow{4}{*}{$\begin{array}{l}\text { Grain } \\
\text { moisture } \\
\text { (\%) }\end{array}$} & \multicolumn{3}{|c|}{$\begin{array}{l}\text { Sowing density } \\
\text { (grain number } \mathrm{m}^{-2} \text { ) }\end{array}$} & \multirow[t]{2}{*}{$\begin{array}{l}\text { Average } \\
(\%)\end{array}$} & \multicolumn{2}{|l|}{ LSD } & \multirow[t]{2}{*}{$\mathrm{C}_{\mathrm{V}}$} \\
\hline & & 160 & 120 & 80 & & 0.05 & 0.01 & \\
\hline 2010 & & 14.09 & 15.79 & 14.99 & 14.96 & 1.79 & 2.42 & 7.09 \\
\hline 2011 & & 16.28 & 15.50 & 14.29 & 15.36 & 1.95 & 2.64 & 7.52 \\
\hline $2010 / 2011$ & & 15.19 & 15.65 & 14.64 & 15.16 & 1.29 & 1.72 & 7.32 \\
\hline
\end{tabular}

\section{CONCLUSIONS}

Different sowing density influnces grain yield of some genotypes and average grain yield in different sowing density variants while average grain yield in investigation years do not vary significantly. The highest average grain yield is obtained in density of 160 grains per $\mathrm{m}^{-2}$, then in density of 120 grains per $\mathrm{m}^{-2}$, but the lowest in 80 grains per $\mathrm{m}^{-2}$ density. Difference in grain yield between 160 grains per $\mathrm{m}^{-2}$ and 120 grains per $\mathrm{m}^{-2}$ density variants is a slight, only $80 \mathrm{~kg}$ or $3.49 \%$ that means both sowing density variant could be applied successfully in buckwheat planting technology, but sowing density of 120 grains per $\mathrm{m}^{-2}$ has priority because of production economics. Various sowing density did not influence grain moisture in both of years.

\section{ACKNOWLEDGEMENTS}

This study is the part of project TD31054 (2011 - on going), supported by the Ministry of Education, Science and Technological Development of Government of Republic of Serbia.

\section{REFERENCES}

Arsic I, Drazic S and Jevdjovic R. 2008. Medicinal traits of buckwheat. IX days of medicinal plants. Kosmaj, Proceedings of Abstracts. pp. 108-109. (Sr) 
Barac S, Biberdzic M, Djikic A. and Milenkovic B. 2012. Effects of the threshing harvester device and its influence on the breakage and damage of the buckwheat and rye depending on predefined parameters. Agriculture \& Forestry, 58 (2): 7-17.

Bavec M, Bavec F, Plazovnik C and Grobelnik S. 2006. Buckwheat leaf area index and yield performance depending on plant population under full-season and stubblecrop growing periods. Die Bodenkultur, 57 (1): 5-12

Bavec F, Bavec M. 2006. Organic production and use of alternative crops. Books in Soil, Plants and the Environment, Vol. 116; Taylor \& Francis CRC Press;Boca Raton, New York, London, pp. 65-78.

Dedic D. 2012. The influence of genotype and sowing density on yield and grain quality of buckwheat (Fagopyrum esculentum Moench.) as. Stubblecrop. Master thesis. Educons University, Sremska Kamenica, Serbia. (Sr)

Gadzo D, Djikic M, Muminovic S. and Hadzic A. 2007. The possibilities of production of buckwheat in Bosnia and Herzegovinia. Abstracts of $42^{\text {nd }}$ Croatian \& $2^{\text {nd }}$ International Symposium on Agriculture, 163

Gadzo D, Kreft I, Djikic M, Hadzic A, Gavric T. and Fajic S, 2009. The importance of increasing of buckwheat in FBH. Proceedings of Papers XX Conference of Agriculture and Food Industry. Neum, pp. 233-238. (Sr)

Gavric T, Čadro S, Gadzo D, Djikic M, Bezdrob M, Jovovic Z, Jurkovic J and Hamidovic S. 2018. Influence of meteorological parameters on the yield and chemical composition of common buckwheat (Fagopyrum esculentum Moench). Agriculture \& Forestry, 64 (4): 113-120.

Hadzvukovic S. 1973. Statistical methods (apllied in agricultural and biological investigations) University in Novi Sad, Novi Sad. (Sr)

Glamoclija Dj, Glamoclija M. and Cvijanovic G. 2011. Buckwheat - economic importance, originate and areas, biological and morphological traits, planting conditions, technology of production, grain processing, preparing food of grain and flour. Faculty of Agronomy, University of Belgrade. Belgrade. (Sr)

Janovska D, Kalinov J. and Michalova A. 2008. Metodika pěstování pohanky obecné v ekologickém a konvenčním zemědělství, Výzkumný ústav rostlinné výroby, v.v.i.,Zemědělská fakulta Jihočeské univerzity v Českých Budějovicích, pp. 114

Kreft I, Fabjan N. and Yasumoto K. 2006. Rutin content in buckwheat (Fagopyrum esculentum Moench) food materials and products. Food Chemistry, 9 (3): 508512.

Kreft I, Germ M. 2008. Organically grown buckwheat as a healthy food and a source of natural antioxidants. Agronomski glasnik, 4: 397- 406.

Li SQ, Zhang QH. 2001. Advances in the development of functional foods from buckwheat.Crit Rev Food SciNutr. Sep;41(6):451-64.

Ohnishi O, Yusui Y. 1998. Search for Wild species in high mountain region of Yunnan and Sichuan provinces of China. Fagopyrum 15: 8-17.

Omid BR, J. Bernath and H. Zakizadeh, 2002. Nitrogen fertilization efficiency of buckwheat (Fagopyrum esculentum Moench) grown at various plant densities. Novenytermeles, 51 (3): 315-321. 
Pausheva, Z. P., 1976. Inheritance of characters in buckwheat. Genetika, selektsiya, semenovodstvo i vozdelivaniegrechikhi. pp. 28-31 .

Popovic, V., V. Sikora ,J. Ikanovic, V. Rajicč̌, I. Maksimovic and S. Katanski, 2013. Production, productivity and quality of buckwheat in organic growing systems in course environmental protection, XVII Eco-Conference, Novi Sad. pp.395-404.

Popović, V., V. Sikora, J. Berenji, V. Filipovic, Z. Dolijanovic, J. Ikanovic and D. Doncic, 2014. Analysis of buckwheat production in the world and Serbia. Economics of Agriculture, Belgrade, 61 (1): 53-62.

Rotim S., B. Stipesevic, F. Bavec, I. Jug, D. Jug, B. Brozovic and M. Stosic, 2012. Technological methods buckwheat planting. .5th International Scientific /Professional Conference Agriculture in nature and environment protection. Proceedings of Abstracts. Vukovar. pp. 334-338.

Zhan-Lu, Z., Z. Mei-Liang , T. Yu, L. Fa-Liang, T. Yi-Xiong, S. Ji-Rong, X. WenTong and W. Yan-Min, 2012. Bioactive compounds in functional buckwheat food.Food Research International, 49, (1): 389-395

Wallace, J., 2001. Organic field crop handbook. $2^{\text {nd }}$ ed. Ottawa: Organic Growers, Inc., www.cog.ca/ofch.htm. 